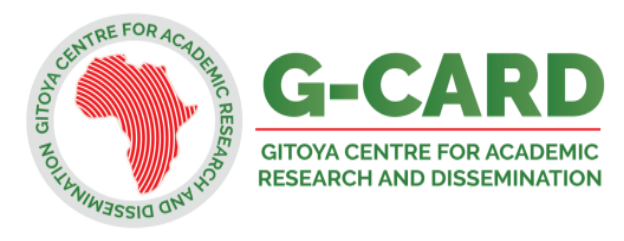

\title{
Perceived Influence of Financial Disbursement on School Quality Assurance in Nyamagana District, Tanzania
}

\author{
Suzana Mbwana and Daniel Oduor Onyango, PhD \\ Saint Augustine University of Tanzania \\ Corresponding Mail: suzanmutta@gmail.com
}

\begin{abstract}
This study sought to investigate on the perceived influence of financial disbursement on school quality assurance in Nyamagana District. The study used a mixed study approach that involves the use of both qualitative and quantitative data in a single study. The study population comprised of 198 selected school stakeholders and the sample was 78 school stakeholders. A single interview guide and a questionnaire were used during data collection. Quantitative data was analyzed through descriptive statistics using the Statistical Package for Social Science (Version 21.0) while qualitative data was analyzed through the thematic approach. The findings of the study showed that adequate funds are important for school quality assurance officers to function effectively. Furthermore, the adequate supply of funds for quality assurance purposes have added advantages like increasing the quality of students' and teachers' performance, propelling teachers' professional development as well as enhancing the confidence of teachers in the process of teaching and learning. The study recommends that the government should disburse adequate funds to support Quality assurance activities in schools, recruit more qualified quality assurers and offer regular training to enable them to effectively perform all activities which are required when they visit schools. Quality assurers should do their job effectively to make sure schools have good environment to enhance quality learning for big results.
\end{abstract}

Keywords: Financial Disbursement, School Quality Assurance, disbursement, Quality Assurance

\section{Introduction}

Quality assurance is very important in ensuring the realization of quality education as specified in sustainable development goals. School quality assurance is an internal and external process of promoting, supporting and imparting agreed quality standards for all aspects of school life to ensure that acceptable standards are attained and that there is a continuous improvement (URT, 2017). School Quality Assurance was initially known as the school inspection, which originated from France in the last quarter of the $18^{\text {th }}$ century (Grauwe, 2007). In Tanzania, Inspectorate Division as a department began during British and German colonial rule and its development has been categorized into four periods namely school inspection from 1903 to 1919 (German colonial rule); school inspection during British rule (1919 to 1925); school inspection from 1925 to 1961 and school inspection after 1961 whereby the emphasis was to support teachers to fulfill their responsibilities (JMT, 2006).
The previous report shows that the inspectorate division experienced low disbursement of funds from the government. For example, while presenting the 2013/14 education budget estimates in the parliament on $4^{\text {th }}$ June 2013 , the Minister for Education Hon. Shukuru Kawambwa admitted that the sector faced serious financial and human resource constraints. According to the Minister, the deficit had affected the ministry's capacity to inspect schools and colleges that would have ensured adherence to the agreed teaching and learning standards. Taken as an acknowledgment of inadequacy, the minister pointed out that departmental capability to inspect is falling below $50 \%$ of schools and colleges planned to be inspected, which left over a half of the existing learning institutions (schools and colleges) uninspected every year (URT, 2013).

In 2017, the inspectorate division adopted a new approach of School Quality Assurance which is in a 
more holistic approach that focuses on the improvement of school performance. Implementation of this new framework is based on the following six domains: (1) learners' achievement, (2) the quality of teaching for effective learning and assessment, (3) the quality of the curriculum in meeting learners' needs, (4) the quality of leadership and management, (5) the quality of the environment and its impact on welfare (6) health, safety and community engagement.

According to URT (2017), during inspection, various resources are needed such as stationeries, record books, lesson observation forms, Pre Visit Preparation plan (PVP) and school summary report cards. Therefore, in order to meet the national SQA targets, adequate budget is required to cater for logistics, allowances, office and general supplies, vehicle maintenance and fuel as well as School Summary Reports Cards preparation (SSRC). In addition to that, a report from Nyamagana District Education office (2020) revealed that the disbursement of the funds was below $50 \%$ which is insufficient. As a result, school quality assurers were unable to visit schools, give advice and support development activities. Hence, it is on this basis that the researchers sought to investigate on the perceived influence of financial disbursement on school quality assurance in Nyamagana District.

This study was further prompted by the fact that school quality assurance is an internal and external process of promoting, supporting and imparting agreed quality standards for all aspects of school life, to ensure that acceptable standards are attained and that there is a continuous improvement. School quality assurance division is responsible for the management of preprimary, primary, secondary, adult education, vocational training and special education (URT, 2017). Therefore this department is very important in ensuring that quality education is maintained in Tanzania.

Kabati (2017) found that school quality assurance plays a potential role in improving teaching and learning. The advice and feedback given through inspection reports and recommendations are useful in improving schools standards. While in 2017 the government of Tanzania restructured the inspectorate division and adopted a new name which is School Quality Assurance Unit, the changes of the name went together with changes in responsibilities; while the model of school inspection previously employed inspectors who focused much on process, with little emphasis on outcomes, the new approach is based on the outcome and capacity building through school selfevaluation (URT, 2017). To carry out its functions effectively, the department requires funds to buy stationery, pay allowances, procure office and general supplies and for vehicle maintenance.

During the cost-sharing era under circular no 1 of 2013, the government allowed each student to contribute 1000 Tanzania shillings to support school quality assurance activities. In 2015, due to the implementation of a fee-free education policy, the government banned all kinds of contributions by students; as a result, the collection of funds by schools to support the quality assurance division became very difficult. It is from this background that the researcher sought to assess the perceived influence of financial disbursement on school quality assurance in Nyamagana District.

\section{Research Methodology}

This portion presents the methodology that guided the study. Particularly, it addresses such issues as the research design, the population and sampling procedures and ethical considerations.

\section{Research Design}

The researchers used a convergent parallel research design which involves the simultaneous collection and analysis of quantitative and qualitative data. Thus, it is used for converging and subsequent interpretation of quantitative and qualitative data together.

\section{Population and Sampling}

This study was conducted in Nyamagana District which is one of the 7 Districts of Mwanza Region. It is bordered to the North by Ilemela District, to the East by Magu District, to the South by Misungwi District and to the West by Lake Victoria. Nyamagana District has 135 schools of which 80 are primary and 55 are secondary. The district has 9 school quality assurance officers, 12 ward educational officers and 42 zonal school quality assurance officers. Furthermore, it has 55 Heads of Secondary Schools and 80 Heads of Primary Schools. Therefore, the population in this study was 198 selected school stakeholders (Nyamagana District Education Office, 2020). The researchers obtained the sample by using the Huysamen formula (Huysamen, 1991) which has it that $40 \%$ of the total 
population could be an appropriate sample as reflected in Table 1:

Table 1: Population and Sampling

\begin{tabular}{llccc}
\hline SN & \multicolumn{1}{c}{ Category } & Population & Data formula & Sample Size \\
\hline 1 & Head of secondary schools & 55 & $40 / 100 \times 55=$ & 22 \\
2 & Head of primary schools & 80 & $40 / 100 \times 80=$ & 32 \\
3 & Zonal School Quality Assurers & 42 & $40 / 100 \times 42=$ & 17 \\
4 & District School Quality assurers & 9 & $40 / 100 \times 9=$ & 3 \\
5 & Ward Education Officers & 12 & $40 / 100 \times 12=$ & 4 \\
& Total & 198 & & 78 \\
\hline
\end{tabular}

\section{Ethical Considerations}

In this study, ethics were considered. Before heading to the field to collect data, the researchers obtained the permission from Saint Augustine University of Tanzania, Mwanza Regional Administrative Secretary and Nyamagana District Administrative Secretary. The researcher informed respondents in advance to get their consent. They were also ensured confidentiality of the information shared, anonymity, privacy and the researchers avoided harming respondents.

\section{Findings of the Study}

The study aimed to establish the perceived influence of financial disbursement on school quality assurance activities in Nyamagana District. The study used questionnaires and interview guides to get information from the respondents. Through the questionnaires, the researchers obtained data from the heads of secondary schools, heads of primary schools and ward educational officers on the influence of financial disbursement on school quality assurance activities in Nyamagana District. The responses were as shown in figure 1 .

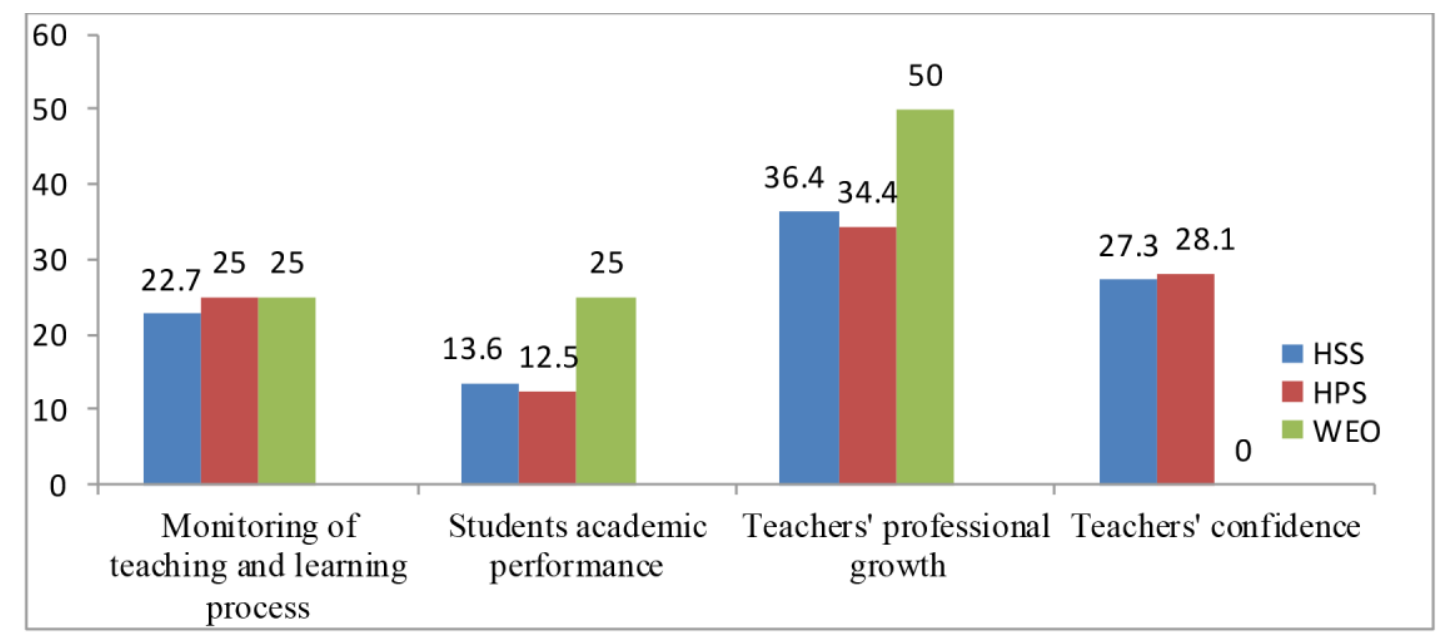

Figure1: The Impact of Financial Disbursement on School Quality Assurance Activities

\section{Monitoring of the Teaching and Learning}

The findings in figure 1 indicate that 25\% of Ward Educational Officers, $25 \%$ of Heads of Primary Schools and $22.7 \%$ of Heads of Secondary Schools perceived that financial disbursement affected monitoring of the teaching and learning process. This suggests that about a quarter of the respondents perceived that when adequate financial disbursements are made to school quality assurance, teaching and learning can be monitored effectively by the quality assurance officers. Information from the interview schedule indicated how funds are necessary for effective quality assurance practice;

When the government disburses funds to the school quality assurance office, we use them for monitoring the teaching and learning process to ensure that teachers have capabilities in teaching, to inform the government about the learning environment and to find out if curriculum materials are present and are followed. We also look for the presence of school committees and encourage the community to own

3 East African Journal of Education and Social Sciences (EAJESS) 2(2)1-6 
their schools by engaging in different activities (Interviewee E).

The findings from interviews also indicate that when the government disburses funds to schools, the quality assurance officers can monitor the teaching and learning processes effectively so as to improve students' academic performance. Therefore, a shortage of funds would negatively affect the proper monitoring of teaching and learning processes in schools.

\section{Students' Academic Performance}

Figure 1 also shows that 25\% of Ward Educational Officers, $13.6 \%$ of Heads of Secondary School and $12.5 \%$ of Heads of Primary School responded that financial disbursement improves students' academic performance.

The findings suggest that school stakeholders consider adequate financial disbursements are likely to improve the students' academic performance. This could be due to the fact that when school quality assurers get sufficient funds, they visit schools regularly to perform their duties. As a result, teachers also perform well in their activity which contributes to high academic performance of students.

The study conducted by Lupimo (2014) supports this finding by indicating that, it is true that effective inspection of schools improves academic performance. Through the interview, it was revealed that adequate financial disbursement has a great impact on students' academic performance due to frequent visit of quality assurers to schools. They also made it clear that insufficient funds leads to failure to visit some schools especially those which perform better. One of the interviewees, for instance, noted;

$$
\begin{aligned}
& \text { Because of the shortage of } \\
& \text { funds, we visit only those } \\
& \text { schools with poor national } \\
& \text { examination results so as to } \\
& \text { improve their academic } \\
& \text { performance. If funds could be } \\
& \text { disbursed as we budgeted, it } \\
& \text { could facilitate visitation of all } \\
& \text { schools and this would give us a } \\
& \text { chance of assisting the schools } \\
& \text { (Interviewee F). }
\end{aligned}
$$

The findings from interviewee $F$ further revealed that schools that were frequently visited posted were likely to post good results as compared to schools that were rarely visited. This means that whenever a school is visited, they can identify its performance gaps and advise on what to do to improve the performance. This finding concurs with that of Carhart (2016) who observed that there was a clear connection between disbursement of funds and students' academic achievement. Therefore the government needs to disburse funds for school quality assurance officers on timely basis to determine good academic performance.

\section{Teachers' Professional Growth}

The findings from figure 1 further shows that $36.4 \%$ of Heads of Secondary Schools, $34.4 \%$ of Heads of Primary School and $50 \%$ of Ward Educational Officers perceived that adequate financial disbursement channeled into Quality assurance activities resulted into the teacher's professional growth. The finding from an interview supported this view as follows:

It is very important as a school to undergo quality assurance activities because it leads to professional growth due to the constructive comments on how to enhance effective learning. Therefore, adequate funding is required to enable the professional growth of teachers through the influence of quality assurance officers [Interview, Interviewee L].

\section{Teachers' Confidence}

Teachers' confidence was another variable which was investigated. Figure 1 indicates that $22.7 \%$ of Heads of Secondary School and $28.1 \%$ of Heads of Primary School perceived that financial disbursement affects teachers' confidence in a positive way. This could be due to the fact that adequate financial disbursement would facilitate school quality assurers to assess teachers and give feedback upon completion of their assessment. The feedback given would guide the teachers to seek appropriate professional growth which ultimately builds teachers' confidence in the teaching and learning process. This finding agrees with that of Kebaso (2012) who opined that teachers who miss strong assistance from school quality assurers are not confident and they sometimes use improper methods of teaching which may affect students' academic achievement and this would lead schools to register low performance.

The findings from the interview further indicate that adequate financial disbursement influences teachers' confidence. One of the interviewees, for instance, reported that "we as school quality 
assurance officers builds teachers' confidence in the class and outside the class by giving them guidelines and standards which are required in the teaching and learning process" (Interviewee K).

According to Kebaso (2012), teachers who lack strong assistance from school quality assurers are not confident and they sometimes use improper methods of teaching which may affect students' academic achievement.

Therefore, the government should increase the number of school quality assurers to enable them perform required activities effectively in order to increase teachers' confidence.

\section{Conclusion and Recommendations}

This part presents the conclusions and gives the recommendations for the study.

\section{Conclusion}

The study concludes that frequent quality assurance practice is required to increase the teaching and learning effectiveness. Furthermore, the adequate supply of funds for quality assurance purposes have added advantages like increasing the quality of students' and teachers' performance, propelling teachers' professional development as well as enhancing the confidence of teachers in the process of teaching and learning. Thus teachers should not take quality assurance as intimidation rather a great opportunity for personal and professional development in terms of content/subject matter, methodologies, classroom management and other aspects.

\section{Recommendations}

Based on the conclusions above, the researchers recommend that the government should disburse adequate funds to support Quality assurance activities in schools, recruit more quality assurers and offer regular training to enable them to effectively perform all activities which are required when they visit schools. Quality assurers should do their job effectively to make sure schools have good environment to enhance quality learning for big results. Finally, teachers should take responsibilities to create conducive environment for learning to take place and to upgrade their knowledge and skills through the inputs from the quality assurers.

\section{Reference}

Carhart, E. A. (2016). School finance decisions and academic performance: An analysis of the impacts of school expenditures on student performance.

(Published master's dissertation). California State University, Sacramento.

Cohen, L., L, Monion \& Morrison, K. (2007). Research Methods in Education ( $\left.6^{\text {th }} \mathrm{ed}\right)$. NewYork : Routledge

Edmonds,W. A \& Kennedy, T.D.(2017). Convergent parallel approach. An applied guide to research designs: Quantitative and qualitative and mixed methods ( $2^{\text {nd }}$ ed). New Delhi, SAGE Publication

Creswell, J. W. (2012). Educational Research:Planning, Conducting and Evaluating Quantitative and Qualitative Research $\left(6^{\text {th }}\right.$ ed). Michgan: Pearson

ET 2020 Working Group (2017). Quality assurance for school development: Guiding principles for policy development on quality assurance in school education. International Journal: Social science and educational Studies, 5 (1) 2409 - 1294.

European Commission Directorate (2018). General for Education and culture Youth, Sports and Multingualism. Paris: UNESCO.

Grauwe, A. (2007). Transforming school supervision into a tool for quality improvement. In international Review of Education, 709714.T

Huysamen, G. K. (1994). Methodology for social and behavioral science $\left(1^{\text {st }} e d\right)$. Johannesburg: Southern Book Publishers.

JMT, (2006). Kiongozi cha Mkaguzi wa Shule. Dar es Salaam: Wizara ya Elimu na Mafunzo na Ufundi.

Kabati, J. (2017). The Effectiveness of School Inspectors in Assuring the Quality of Primary Education: A case study of Shinyanga District. (Published master's dissertation). Open University of Tanzania, Shinyanga. Tanzania.

Kebaso, G. N. (2012). Influence of quality assurance and standard officers' practices on students' performance in Kenya certificate of secondary education in public schools. A case study of Masaba North District. (Published master's dissertation). University of Nairobi, Kenya.

Kengara, R. (2014). Effect of Fund Disbursement Procedures on Implementation of Donor

\section{East African Journal of Education and Social Sciences (EAJESS) 2(2)1-6}


Projects in Homa Bay County, Kenya. Universal Journal of Accounting and Finance, 2 (1), 9-23.

Kombo, J. \& Tromp, M. (2006). Proposal and thesis writing. Payline Publication Africa, Kenya.

Koskei, A.C. (2017). Influence of disbursement time of free primary education funds on the management of schools by head teachers in Uasin Gishu County, Moi University Kenya. International journal of education and Learning and Development. 5(3), 59-71

Kothari, C. R. (2006). Research Methodology and Techniques, $\left(2^{\text {nd }}\right.$ ed). New Delhi: New Age International $(\mathrm{P})$ limited.

Leedy, P, D., \& Ormrod, J. E. (2013). Practical research planning and design $\left(10^{\text {th }}\right.$ ed.). Boston, MA: Pearson Education.

Lupimo, M. F. (2014). The role of School Inspection in Improving Academic Performance in Community Secondary Schools in Tanzania: A case study of Bariadi District. (Published master's dissertation). Mzumbe University, Dar es Salaam Campus.

Lyimo, P. L. (2015). The impact of school inspection on students' academic achievement: a study of Mbeya City District. (Published Master's Dissertation). Oslo University.

Matete, E. R. (2009). The Impact of Primary School Inspection on teaching and learning in Tanzania: A study of Mbeya City District. Educational research Oslo, Comparative and International Education Institute, University of Oslo Master of philosophy: 142

Matthew, I. A. (2012). The challenges facing schools inspection Amid Universal Basic Education (UBE) implementation in Nigeria. International Journal of Learning and Development, 2(5), 203-214..

Mueni, K. R., Peter, K. R., \& Mulwa, D. (2019). Impact of Prompt Disbursement of Free Public secondary Schools in Makueni County Kenya. International Journal of Education and Research. 7 (11), 2411-2681
Mugenda, O. \& Mugenda.A. (2003). Research methods: quantitative and qualitative methods ( $2^{\text {nd }} e d$.). Nairobi: Acts Press.

Oso, W. Y \& Onen, D. (2016). Writing Research Proposal and Report: A handbook for beginning researchers. Nairobi Kenya: Ramco Printing Works Ltd.

Ryan, T. (2015). Quality assurance in higher education: A review of literature. Higher learning research communications, 5(4), 1.

Silverman, D. (2000). Doing qualitative research Practical handbook. London: Sage

Smith, A. J. (2011). Evaluating the contribution of interpretative phenomenological analysis. Health Psychology Review, 5 (1), 9 - 27

Teklemariam, T, A. (2009). Human Resource Management for Educational Practitineries in Africa. Nairobi : CUAE Press.

UNESCO (2017). Enhancing teaching learning through internal quality assurance. Xiamen University, China. Retrieved from www. iiep. unesco.org

UNESCO (2017). Global Monitoring Report 2017/2018: Teaching and Learning achieving Quality for all $\left(1^{\text {st }}\right.$ ed). Paris: UNESCO.

URT (2011). School Inspectors Supervisors Manual Dar es Salaam: MoEVT:

URT (2011). School Inspectors' Training Manual: (3 ${ }^{\text {rd }}$ ed) .Dar es Salaam: MoEVT

URT (2017). School Quality Assurance: Handbook. Dodoma: MoEST.

URT (2017). School Quality Assurance: Operational Manual. Dodoma: MoEST.

Wintermann, O. (2014). Global Economic Symposium. Retrieved from w.w.w. globaleconomic. org.

Zohrabi, M. (2013). Mixed method research: Instruments, validity, reliability and reporting findings. Theory and Practice in Language Studies, 3(2), 254- 262. 